\title{
MULTIKULTURALISMUS A INTEGRAČNÍ PRÁVO V KANADĚ
}

\author{
HARALD CHRISTIAN SCHEU, ELIŠKA NOVÁČKOVÁ
}

\begin{abstract}
Multiculturalism and Integration Law in Canada
This paper presents the Canadian concept of multiculturalism, which understands the ethnic and cultural diversity of society as an important value and aims to protect all minorities, including those most vulnerable. The analysis of the legal foundation of the principle of multiculturalism and its application in the practice of Canadian courts demonstrates how the principle of multiculturalism should contribute to the protection of human rights and minority rights. In 1982, the Canadian Charter of Rights and Freedoms was adopted as an integral part of the Canadian Constitution. The Charter contains, in addition to traditional civil and political rights, a provision according to which the Charter is to be interpreted in a manner consistent with the preservation and enhancement of the multicultural heritage of Canadians. After analyzing the cases in which Canadian courts have referred to the principle of multiculturalism, at the end of the paper it is assessed whether a similar model would also be beneficial for the European protection of human and minority rights.
\end{abstract}

Keywords: principle of multiculturalism; Canada; Charter of Rights and Freedoms; case law; cultural diversity; religious freedom; secularism; freedom of speech

Klíčová slova: princip multikulturalismu; Kanada; Listina práv a svobod; judikatura; kulturní odlišnost; náboženská svoboda; sekularismus; svoboda projevu

DOI: $10.14712 / 23366478.2018 .12$

\section{1. ÚVOD}

Kanadský myslitel Will Kymlicka vydal od 90. let minulého století celou řadu publikací na téma ochrany menšin. ${ }^{1}$ Vedle různých pokusů o kategorizaci národnostních a etnických menšin a vymezení různých menšinových práv ho proslavila zejména jeho koncepce multikulturalismu, která slad’uje politický liberalismus s poskytováním skupinových práv. Spolu se dvěma dalšími kanadskými teoretiky, s Charlesem Taylorem a Jamesem Tullym, je Will Kymlicka považován za jednoho z nejvýznamnějších zastánců teorie multikulturalismu. ${ }^{2}$

1 Viz napr. KYMLICKA, W.: Multicultural Citizenship. Oxford, 1995; KYMLICKA, W.: Multikulturalismus und Demokratie. Über Minderheiten und Nationen. Hamburg, 1999; KYMLICKA, W.: Politics in the Vernacular. Nationalism, Multiculturalism, Citizenship. Oxford, 2001; KYMLICKA, W.: Multicultural Odysseys. Navigating the New International Politics of Diversity. Oxford, 2007.

2 Podrobněji HEINS, V.: Der Skandal der Vielfalt. Geschichte und Konzepte des Multikulturalismus. Frankfurt nad Mohanem, 2013, s. 85-97. 
Během svého působení na Středoevropské univerzitě v Budapešti v roce 2002 se Kymlicka mimo jiné zabýval otázkou, nakolik lze západní koncepci multikulturalismu implementovat do zemí postkomunistické Evropy. Po stručném rozboru pozitivního př́ínosu multikulturního př́stupu nap̌r. v oblastech demokracie, lidských práv, hospodářské prosperity i rovnosti mezi skupinami Kymlicka vyzdvihl hlavní neúspěch multinárodních federací, který spočívá ve slabé mezikulturní interakci jednotlivých skupin. $\mathrm{Na}$ príkladech Belgie a Kanady lze dokumentovat vznik paralelních společností. ${ }^{3}$ Za nejdůležitější rozdíl mezi západním a východním př́stupem k právům a autonomii menšin považuje Kymlicka vědomí o spojení mezi menšinovou otázkou a problémem vnitřní i vnější bezpečnosti. Zatímco západní státy podle Kymlicky „desekuritizovaly“ problém postavení menšin ve státě, východní státy na základě historických zkušeností vnímají menšiny často jako potenciálního nepř́tele, který se může chovat neloajálně ke státu a stát se „pátou kolonou“ nepřátelských sousedních států. ${ }^{4}$

Rozdílné vnímání multikulturní politiky je realitou i v současné Evropě. Těžiště diskuse se mezitím výrazně posunulo od ochrany tradičních národnostních menšin do řešení integrace přistěhovalců jako př́slušníků tzv. nových menšin. V roce 2011 Evropská komise představila svoji Evropskou agendu pro integraci státních př́slušníků třetích zemí, ve které výslovně konstatovala: „Pokud chce Evropa plně využít př́nosů migrace, musí nalézt způsob, jakým se - prostřednictvím účinnějšś integrace migrantů - lépe vypořádá se svými různorodými a multikulturními společnostmi. " ${ }^{5}$ Nový akční plán, který Komise předložila v roce 2016, je poněkud opatrnější, co se týče zvolené formulace. Výraz „multikulturní společnost“ se v něm už nevyskytuje, ale v duchu stejné filozofie Komise hovoří nyní o „přívětivé a rozmanité společnosti vstřícné vůči začleňování“6 a požaduje mezikulturní a mezináboženský dialog. ${ }^{7}$

Přístup k přistěhovalcům zejména z odlišných kulturních oblastí a určení podmínek jejich začlenění do společnosti v současné době štěpí EU. ${ }^{8}$ Nejde jen o problém samotného přijetí uprchlíků na své území na základě relokačních rozhodnutí, který souvisí s postupnou komunitarizací migrační a azylové agendy a složitým vymezením pravomocí EU a členských států $\mathrm{v}$ této věci. Za současnými konflikty uvnitř se skrývají hlubší rozpory, které vycházejí z odlišných historických zkušeností a odlišných koncepcí ná-

3 KYMLICKA, W.: Multiculturalism and Minority Rights. West and East. Journal on Ethnopolitics and Minority Issues in Europe, 2002, č. 4, s. 10-13.

4 Tamtéž, s. 19-21.

5 Sdělení Komise Evropskému parlamentu, Radě, Evropskému hospodářskému a sociálnímu výboru a Výboru regionů Evropská agenda pro integraci státních př́slušníků třetích zemí. KOM / 2011 / 455 v konečném znění.

6 V angličtině: ,,welcoming, diverse and inclusive societies“.

7 Sdělení Komise Evropskému parlamentu, Radě, Evropskému hospodářskému a sociálnímu výboru a Výboru regionů. Akční plán pro integraci státních př́slušníků třetích zemí. KOM / 2016 / 377 v konečném znění.

8 Refugee Crisis: a new East-West rift in Europe? Interview with Luks Macek, Director of the European Campus - Central and Eastern Europe/Sciences Po Paris. European Interview, 26.10.2015, č. 88, dostupné z: https://www.robert-schuman.eu/en/doc/entretiens-d-europe/ee-88-en.pdf; GYÖRI, G.: The Political Communication of the Refugee Crisis in Central and Eastern Europe. Budapešt', 2016. 
rodního státu v EU. ${ }^{9}$ Zdá se, že rozdíly mezi Západem a Východem, které se před více než 15 lety snažil paradigmaticky uchopit Kymlicka, žijí dále v trochu jiné podobě.

Ve světle současných rozporů kolem aplikace multikulturní politiky se chceme v tomto prŕspěvku vrátit ke kořenům multikulturní filozofie a podrobněji zkoumat kanadský model multikulturalismu. Pomocí analýzy právního zakotvení principu multikulturalismu a jeho aplikace v praxi kanadských soudů má být doloženo, v čem spočívá př́nos multikulturalismu v kontextu lidských práv a práv menšin. Cílem příspěvku je posoudit, zda by obdobný model byl prŕnosný také pro evropskou ochranu lidských práv.

\section{VYMEZENÍ PŘEDMĚTU STUDIE}

Vyjasnění pojmu multikulturalismu rozhodně nepřispívá jeho inflační používání v politické debatě. Ani odborná literatura nenabízí jednotnou definici koncepce. Odborníci na politickou teorii a sociologii se zabývají např. uznáním kulturní odlišnosti, hodnotou kulturní rozmanitosti a politikou inkluzí. Tyto koncepce však nelze jednoduše převzít do právní teorie a praxe. Vzhledem $\mathrm{k}$ absenci přesné právní definice samotného pojmu kultury ${ }^{10}$ lze říci, že paradigma multikulturalismu představuje z pohledu práva spíše vágní politickou strategii než právní pojem.

Pro účely tohoto článku se zaměříme na multikulturalismus jako princip, který je zakotven v právních normách. Ačkoliv nelze zcela abstrahovat od skutečnosti, že multikulturalismus má zpravidla politický kontext, budeme zkoumat pouze př́pady, ve kterých politika multikulturalismu je opřena o konkrétní právní normy a nástroje. Politiku multikulturalismu oficiálně vyhlásily Kanada a Austrálie, a to v souvislosti s ochranou etnické, kulturní, náboženské a jazykové rozmanitosti země. V obou zemích se může multikulturalismus jako politická strategie promítat i do výkladu a aplikace lidských práv a práv menšin. ${ }^{11}$

Nejzřetelnější vazbu mezi politikou multikulturalismu a právem nabízí kanadská úprava. V roce 1982 byla přijata kanadská Listina práv a svobod (dále jen Listina) jako nedílná součást kanadské ústavy. Listina obsahuje tradiční občanská a politická práva a věnuje netradičně velký prostor jazykovým právům a právům menšin. Do obecných ustanovení Listiny bylo začleněno ustanovení čl. 27, ${ }^{12}$ podle něhož Listina má být vykládána způsobem odpovídajícím zachování a rozšíření multikulturního dědictví Kanad’anů. Ve světle citovaného ustanovení je na kanadských soudech, ${ }^{13}$ aby jednak vymezi-

9 Srov. např. MORILLAS, P. (ed.): Illiberal democracies in the EU. The Visegrad Group and the risk of disintegration. Barcelona, 2017; NIČ, M.: The Visegrád Group in the EU: 2016 as a turning point? European View, 2016, č. 2, s. 281-290.

10 K různým pojetím kultury viz např. LENSKI, S.-C.: Öffentliches Kulturrecht. Materielle und immaterielle Kulturwerke zwischen Schutz, Förderung und Wertschöpfung. Tübingen, 2013, s. 17-29.

$11 \mathrm{~K}$ historickým kořenům politiky multikulturalismu viz MANN, J.: The introduction of multiculturalism in Canada and Australia, 1960s-1970s. Nations and Nationalism, 2012, č. 3, s. 483-503.

12 Pro podrobnou genezi čl. 27 Listiny viz UBEROI, V.: Multiculturalism and the Canadian Charter of Rights and Freedoms. Political Studies, 2009, č. 4, s. 805-827.

13 Podle čl. 24 Listiny se může kdokoli, jehož práva či svobody garantované Listinou byly porušeny či odepřeny, obrátit na soud příslušné jurisdikce za účelem zjednání nápravy tak, jak soud uváží za vhodné a spravedlivé dle okolností. 
ly pojem multikulturní dědictví a dále interpretovaly relevantní práva jednotlivců, která jsou v Listině zakotvena, v souladu s principem multikulturalismu. Analýza výkladu čl. 27 Listiny v praxi kanadských soudů představuje těžiště tohoto př́spěvku.

\section{POLITIKA MULTIKULTURALISMU A ZMĚNY V KANADSKÉ SPOLEČNOSTI}

Kanada se stala první zemí na světě, která přijala politiku multikulturalismu, a to $\mathrm{v}$ roce 1971 pod názvem „multikulturalismus v dvojjazyčném prostředí“. Multikulturalismus měl představit opak tradičního bikulturalismu a tradiční dvojjazyčnosti, která směřovala k rovnému partnerství britského a francouzského prvku. Posun od bikulturalismu k multikulturalismu byl politickou odpovědí na požadavky domorodých a imigrantských skupin.

Podle Michaela Dewinga lze chronologii kanadského multikulturalismu členit na tři fáze. ${ }^{14}$ Od konce druhé světové války do roku 1971 proudili do země převážně evropští přistěhovalci a uprchlíci z pobaltských států, Nizozemí, Itálie a Mad’arska, kteří doplnili německé, skandinávské a ruské přistěhovalecké komunity vzniklé v průběhu první poloviny 20. století. Tito přistěhovalci postupně začali zpochybňovat britskou kulturní hegemonii.

Druhá fáze od 1971 do 1981 byla pod vlivem vládou oficiálně vyhlášené politiky multikulturalismu a byla charakterizována výukou jiných jazyků než angličtiny a francouzštiny ve veřejných školách a různými kulturními programy ve prospěch menšin. Cílem politiky bylo zajistit zachování kulturních identit jednotlivých skupin a jejich politickou a společenskou participaci. Agenda multikulturalismu byla také začleněna do struktury veřejné správy.

Během navazující třetí fáze byla politika multikulturalismu kodifikována v právních dokumentech. Vedle již zmíněného začlenění principu multikulturalismu do čl. 27 Listiny práv a svobod byl v roce 1988 přijat speciální zákon o multikulturalismu. Ve svém čl. 3 vymezuje tento zákon jednotlivé charakteristiky politiky multikulturalismu a povinnosti federálních orgánů. V souladu s ustanovením čl. 3 zákona o multikulturalismu mají vláda a další federální orgány např. podporovat povědomí, že multikulturalismus reflektuje kulturní a rasovou různorodost kanadské společnosti a že multikulturalismus uznává svobodu všech členů kanadské společnosti zachovat, rozšiřovat a sdílet jejich kulturní dědictví. Multikulturalismus je označován za základní prvek kanadského dědictví a identity.

V roce 1991 bylo zřízeno ministerstvo pro multikulturalismus a občanství, ${ }^{15}$ pod kterým vznikly konkrétní programy na implementaci politiky multikulturalismu. V roce 1991 byl též přijat zákon zakládající tzv. Canadian Race Relations Foundation, který

\footnotetext{
14 DEWING, M.: Canadian multiculturalism (Background paper). Ottawa, 2009, dostupné z: https://lop.parl .ca/content/lop/ResearchPublications/2009-20-e.pdf.

15 Později byl název ministerstva změněn na Ministerstvo pro kanadské dědictví.
} 
odkazuje na zákon o multikulturalismu a má přispívat $\mathrm{k}$ realizaci multikulturalismu v Kanadě. Od roku 2002 se 27. červen slaví v Kanadě jako Den multikulturalismu. ${ }^{16}$

Posun kanadské společnosti směrem k multikulturalismu dokumentují také sčítání lidu. Podle sčítání lidu z roku 1871 mělo 60 \% obyvatel Kanady britský původ, 30 \% francouzský. V průběhu 20. století se průběžně navýšil podíl evropských přistěhovalců nemajících ani britský ani francouzský původ z 8,5 \% v roce 1901 na 14,2 \% v roce $1921,17,8$ \% v roce 1941 a $23 \%$ v roce 1971 . Po roce 1967 narostl podíl neevropských přistěhovalců z Asie a Afriky. Ještě v roce 1971 Kanad'ané evropského původu tvořili celkem $96 \%$ obyvatelstva. ${ }^{17}$

Od roku 1981 sčítání lidu v Kanadě zaznamenává kategorii tzv. „viditelných menšin“, do které se přihlásilo v roce 1981 4,7 \%, v roce 2001 13,4 \% a v roce 2016 $22,3 \%{ }^{18}$ Tento pojem zahrnuje „osoby jiné než domorodí obyvatelé, kteří jsou nebělošští rasou či nikoli bílí barvou“, tzn. asijské, latinsko-americké a tichomořské ostrovní komunity. ${ }^{19}$ Přehlednost statistického vývoje komplikuje fakt, že v roce 1996 byla zavedena samostatná kategorie „kanadský“، 20

Lze shrnout, že kanadská koncepce multikulturalismu odráží historii přistěhovalecké země. Koncepce vymezená v zákoně o multikulturalismu může být pokládána za opak americké ideologie nazývané melting pot. Na rozdíl od USA kanadský model nevolá po asimilaci menšin do většinové kultury. Pojem kanadského národa implikuje mozaiku různých kultur, nebot' jednotlivé osoby mezi sebou mohou kontrastovat, ovšem společně dotvářejí portrét národa, stejně jako tečky v malbě pointilisty dotvářejí ucelený obraz. $^{21}$

Ve světle demografického vývoje je pochopitelné, že praktická realizace kanadské koncepce multikulturalismu nebude vždy jednoduchá. Z právního hlediska tvoří klíčovou součást multikulturní strategie základní lidská práva a práva menšin. Podobně jako v jiných liberálních demokraciích má výklad těchto práv hledat správnou rovnováhu protichůdných zájmů, a to jak individuálních a skupinových zájmů, tak i legitimních zájmů státu a společnosti. V další kapitole se proto zaměříme na otázku, jak se právně zakotvený princip multikulturalismu promítá do řešení právních sporů před kanadskými soudy a zda aplikace tohoto principu nad rámec běžné lidskoprávní doktríny nabízí přidanou hodnotu pro právní praxi.

16 DEWING, M.: Canadian multiculturalism (Background paper). Ottawa, 2009, s. 5-7.

17 Viz např. LI, P. S.: Cultural Diversity i Canada: The Social Construction of Racial Differences. Department of Justice: Strategic Issues Series - rp02-8e, 2000, dostupné z: http://www.justice.gc.ca/eng /rp-pr/csj-sjc/jsp-sjp/rp02_8-dr02_8/rp02_8.pdf.

$1821.9 \%$ of Canadians are immigrants, the highest share in 85 years: StatsCan. CBC News [online],2017 [cit. 2018-02-08], dostupné z: http://www.cbc.ca/news/politics/census-2016-immigration-1.4368970.

19 Pro definici viz čl. 3 kanadského zákona o rovnosti v zaměstnání (Employment Equality Act, S.C. 1995, c. 44).

20 GUO, S. - WONG, L.: Revisiting Multiculturalism in Canada. An Introduction. In GUO S. - WONG, L. (eds.): Revisiting Multiculturalism in Canada. Theories, Policies and Debates [online]. Rotterdam, 2015, s. 1-14. Dostupné z: http://www.springer.com/gp/book/9789463002080?wt_mc=ThirdParty.SpringerLink 3.EPR653.About_eBook.

21 SCHNEIDER, H.: Canada: A mosaic, not a melting pot. The Washington Post [online], 5. 7. 1998 [cit. 2018-02-07], dostupné z: https://www.washingtonpost.com/archive/politics/1998/07/05/canada-a-mosaic -not-a-melting-pot/8a4998ed-b04b-491e-b72e-1ef4d8e96d84/?utm_term=.f38afac48280. 


\section{MULTIKULTURALISMUS V SOUDNÍ PRAXI}

Kulturní různorodost je v prrípadě Kanady specifická jednak z důvodu zřejmé přítomnosti národnostních menšin, např́iklad obyvatel Quebecu či komunit původních obyvatel, ale také $\mathrm{z}$ důvodu početné řady dalších etnických skupin. ${ }^{22}$ Ačkoli se v řadě rozsudků kanadské soudy hlásí k principu multikulturalismu, přímá argumentace touto hodnotou je velice sporadická a slouží spíše k podpoře jiných hodnot a principů. Uvedená subsidiární aplikace je ovšem v rozporu s cítěním samotných obyvatel, nebot' stále rostoucí většina Kanad'anů považuje multikulturalismus za jeden z nejdůležitějších symbolů národní identity. ${ }^{23}$ Navíc čl. 27 Listiny zdůrazňuje potřebu takového výkladu, který je v souladu s ochranou a šířením multikulturního dědictví Kanad'anů. Rovněž judikatura dokládá, že uvedený článek práva nezakládá, ale naopak slouží jako výkladové hledisko jiných práv a svobod.

Z dosavadní judikatury lze vyvodit, že odkaz na princip multikulturalismu bývá nejčastěji spojován s určitými právy podle Listiny. Proto se chceme zaměřit na aplikaci čl. 27 Listiny v kontextu stíhání nenávistných projevů, vymezování sekularismu a limitů náboženské svobody a antidiskriminačního práva.

\subsection{PRINCIP MULTIKULTURALISMU A PROBLEMATIKA HATE SPEECH}

První soudní odkaz na princip multikulturalismu lze spatřovat v rozhodnutí z roku 1990 zvaném Keegstra, ${ }^{24}$ podle jména středoškolského učitele v malém kanadském městě. Ten byl v roce 1984 obžalován z méně závažného trestného činu podle § 319 trestního zákoníku, a to z veřejného podněcování k nenávisti. Pan Keegstra učil, Že Židé jsou barbarští a sadističtí lidé toužící po penězích a moci. Studenti, kteří přijali jeho názory, dostávali lepší známky než druzí. Poté, kdy byl Keegstra v roce 1985 odsouzen soudem státu Alberta, zpochybnil ústavnost $§ 319$ trestního zákoníku s odůvodněním, že toto ustanovení porušilo jeho svobodu projevu garantovanou v čl. 2 Listiny.

V roce 1990 Nejvyšší soud konstatoval, že předmětný $§ 319$ opravdu zakládá zásah do čl. 2 Listiny, ovšem také dovodil, že omezení svobody projevu je v případech veřejného podněcování k nenávisti důvodné. Soud přitom zdůraznil význam harmonických sociálních vztahů v multikulturní společnosti a výslovně odkázal na čl. 27 Listiny. Většina soudců rozhodla, že ,závazek k multikulturní představě našeho národa znamená zdůraznění naléhavého významu cíle vymýtit nenávistnou propagandu ze společnosti“. Proto soud použil princip multikulturalismu za účelem určení limitů svobody projevu.

22 SCHNEIDERMAN, D.: Multiculturalism in Canadian Constitutional Culture: Domesticating Difference. SSRN [online], 4. 1. 2016, dostupné z: https://ssrn.com/abstract=2710770 nebo http://dx.doi.org/10.2139 /ssrn.2710770.

23 GUO, S. - WONG, L.: Revisiting Multiculturalism in Canada. An Introduction. In GUO, S. - WONG, L. (eds.): Revisiting Multiculturalism in Canada. Theories, Policies and Debates [online]. Rotterdam, 2015 [cit. 2018-01-16]. Dostupné z: http://www.springer.com/gp/book/9789463002080?wt_mc=ThirdParty .SpringerLink.3.EPR653.About_eBook.

24 R. v. Keegstra, [1990] 3 S.C.R. 697. 
Dalším významným př́ípadem spojeným s problémem šírení nenávisti je případ Taylor ${ }^{25}$ který byl též rozhodnut v roce 1990 . V roce 1979 se Kanadská komise pro lidská práva, které byl svěřen dohled nad dodržováním kanadského zákona o lidských právech z roku 1977,26 začala zabývat stížnostmi poukazujícími na telefonní komunikaci J. R. Taylora a strany nazvané Western Guard Party, ve které vystavovali Židy nenávisti a opovržení. Komise dospěla k závěru, že Taylor a Western Guard Party porušili čl. 13 zákona o lidských právech, podle kterého je diskriminačním jednáním opakované telefonní sdělení, na základě kterého může být osoba vystavena nenávisti nebo opovržení z důvodu rasy, národnosti nebo etnického původu, barvy pleti či náboženství. Protože ale zákon nestanoví žádné trestní sankce, nebyla Komise oprávněna ukládat peněžité pokuty. Komise se ovšem po prostudování př́ipadu a neúspěšné snaze o řešení v podobě mediace rozhodla př́pad předložit Tribunálu pro lidská práva, který je podle zákona o lidských právech oprávněn vydávat závazná rozhodnutí např̀ o zákazu diskriminačního jednání.

V daném př́padě Tribunál vydal př́kaz zdržet se takového jednání, a protože Taylor a Western Guard Party pokračovali ve sdělování nenávistných zpráv po telefonu, obrátila se Komise na soud z důvodu neuposlechnutí soudního př́íkazu. Federální soud uložil Taylorovi jeden rok odnětí svobody a Western Guard Party byla povinna zaplatit 5000 dolarů. Taylor se obrátil na Nejvyšší soud a uvedl, že čl. 13 zákona o lidských právech porušuje svobodu projevu zaručenou článkem 2 Listiny. Nejvyšší soud shledal i v tomto př́padě, že čl. 13 zákona o lidských právech byl důvodným omezením svobody projevu, a prohlásil, že šíření nenávisti představuje hrozbu pro společnost. Podle Nejvyššího soudu takové jednání podrývá „důstojnost a sebeúctu členů cílové skupiny a celkově přispívá k nesouladným vztahům mezi různými rasovými, kulturními a náboženskými skupinami, což narušuje toleranci a otevřenost novým názorům, které mají v multikulturní společnosti, vázané ideou rovnosti, vzkvétat“".

\subsection{PRINCIP MULTIKULTURALISMU A SEKULARISMUS}

Mnoho soudních případů lze nalézt $\mathrm{v}$ oblasti posuzování náboženské svobody a hodnot multikulturalismu. Jedním z prvních byl rozsudek ve věci Big M Drug Mart. ${ }^{27} \mathrm{~V}$ roce 1982 byl Big M Drug Mart obviněn z prodeje zboží v neděli, protože takový prodej byl v rozporu se zákonem o dni Pána. Soud prvního stupně konstatoval, že tento zákon porušuje náboženskou svobodu zakotvenou v článku 2 Listiny. Poté, co se generální advokát proti tomuto rozhodnutí odvolal, odvolací soud potvrdil, že některá ustanovení zákona byla nezákonná. Následně se spor dostal k Nejvy̌̌šímu soudu, který měl rozhodnout, zda zákon byl v rozporu s náboženskou svobodou podle čl. 2 Listiny. Nejvyšší soud nakonec rozhodl, že přinucení obecného dodržování dne odpočinku pre-

25 Canada (Human Rights Commission) v. Taylor, [1990] 3 S.C.R. 892.

26 Materiální úprava zákona o lidských právech (Canadian Human Rights Act) obsahovala řadu ustanovení o zákazu diskriminace včetně zákazu nenávistných projevů v čl. 13 zákona. V roce 2013 byl čl. 13 zákona zrušen. Viz podrobněji TOMLINS, S.: The Freedom to Offend? How the "Mohammad Cartoon Controversy” Has Influenced Public Debate on Canada's Hate Speech Regulation. Journal of Church, 2015, č. 1, s. 44-71.

27 R. v. Big M Drug Mart Ltd., [1985] 1 S.C.R. 295. 
ferovaného jedním náboženstvím není souladné s ochranou a šířením multikulturního dědictví. Podle Nejvyššího soudu bylo v rozporu s článkem 27 Listiny právně zavázat věřící i nevěřící pravidlem, které je zakořeněno v křest’anské morálce. Teologický obsah pravidla by náboženským menšinám neustále připomínal jejich kulturní odlišnost. Jinými slovy, Nejvyšší soud uvážil koncept multikulturalismu jako výzvu k přijetí sekulárního př́stupu.

Další případ týkající se náboženské svobody spočíval v rozvodovém řízení kanadských manželů Bruker a Marcovitze, ${ }^{28}$ kteří se vzali v roce 1969. Rozvodové řízení začalo v roce 1980, kdy podepsali dohodu, že po civilním rozvodu proběhne ještě rozvod židovský. Pan Markovitz ale následujících patnáct let odmítal židovský rozvod podstoupit, což pro paní Bruker znamenalo nemožnost opětovně se vdát podle židovských pravidel. Paní Bruker se tak domáhala odškodnění a pan Markovitz argumentoval tak, že uvedená dohoda není dle práva Quebecu platná a že před placením odškodného je chráněn náboženskou svobodou. Soud prvního stupně konstatoval, že dohoda je platná a závazná, nebot' veřejný zájem na ochraně rovnosti práv, důstojnosti židovských žen v možnosti se rozvést a opětovně provdat stejně jako veřejný zájem na vynucování platných a závazných smluv převažuje nad tvrzením pana Markovitze, že vynucování uvedeného závazku by zasahovalo do jeho náboženské svobody.

Nejvyšší soud rozhodl, že ani náboženský kontext smlouvy neznamená, že smlouva nemůže být vynutitelná, pokud jsou splněny její základní předpoklady. Předmětná smlouva je vynutitelná, nebot' jejím předmětem jsou požadavky rozvodu, které nejsou $\mathrm{v}$ rozporu s veřejným pořádkem, ani nejsou v rozporu s náboženskou svobodou. Oslabení náboženské svobody pana Markovitze bylo výrazně převáženo újmou paní Bruker a veřejným zájmem na ochraně rovnosti práv a autonomního rozhodnutí k manželství a k rozvodu. K závaznosti smlouvy soud konstatoval, že náboženské nebo morální závazky lze právně vymáhat, pokud jsou naplněny požadavky kladené na smluvní vztah, protože nikomu není bráněno, aby své morální závazky přeměnil v právně závazné povinnosti. Přijetí principu multikulturalismu z pohledu soudu znamená, že musí zůstat v náboženských otázkách neutrální. Tato neutralita soudy opravňuje k rozhodování při střetu v soužití různých náboženství a umožňuje jim urovnat předmětné právní spory, proto lze uzavř́t, že je v pluralistické a multikulturní společnosti nepostradatelná.

O vyvažování hodnot multikulturalismu a náboženské svobody na jedné straně a bezpečnostního zájmu a ochrany majetku na straně druhé se pokusil Nejvyšší soud v roce 2009 ve věci Hutteritư. ${ }^{29}$ Soud zde hodnotil nařízení státu Alberta z roku 2003, aby všechny osoby, které ř́dí motorová vozidla, měly na řidičském průkazu svoji fotografii. Skupina přibližně 250 hutteritů ovšem považovala pořízení takové fotografie za porušení svých náboženských přikázání, a protože jejich venkovský život a zemědělské aktivity řidičský průkaz vyžadovaly, obrátila se na soud.

Ten aplikoval tzv. Oakes test, v rámci kterého napřed posuzoval cíl nařízení, tedy skutečnost, že databáze fotografií má zajistit propojení s jednotlivými řidičskými průkazy a zamezit podvodům s identitami. Druhým krokem bylo hodnocení, zda je príjaté

28 Bruker v. Marcovitz, [2007] 3 S.C.R. 607, 2007 SCC 54.

29 Alberta $v$. Hutterian Brethren of Wilson Colony, 2009 SCC 37, [2009] 2 S.C.R. 567. 
opatření vhodné ke stanovenému cíli, přičemž i zde Soud souhlasil, že databáze fotografií vytvoří závažné překážky pro pachatele ve snaze užít identitu jiné osoby. V rámci třetího kroku Soud posuzoval, zda je přínos opatření větší než s ním spojené omezení práv. V daném př́padě podle Soudu převážil zájem na bezpečnosti systému řidičských průkazů, bezpečnosti silničního provozu a sjednocení legislativy státu Alberta s dalšími státy nad konkrétním dopadem do náboženské svobody. K tomu Soud uvedl, že v multikulturní společnosti je nevyhnutelný konflikt mezi povinnostmi státních autorit a individuální víry.

Judikát z roku 2015 týkající se střední školy Loyola High School ${ }^{30}$ dokládá, že v multikulturní společnosti není porušením náboženské svobody vyžadovat, aby výuka o doktrínách a etice světových náboženství probíhala neutrálním způsobem. Ovšem současně je připuštěno, aby tuto výuku zajišt'ovaly i náboženské školy, nebot' nejen, že u nich není vyloučena možnost vyučovat jiná náboženství neutrálním a respektujícím způsobem, ale dokonce lze $\mathrm{v}$ jejich př́padě takový př́istup předpokládat. $\mathrm{V}$ uvedeném sporu se jednalo o soukromou katolickou školu Loyola High School, vedenou jezuity v anglickém jazyce. Od záŕí 2008 měl být v hlavních osnovách na všech středních školách v Quebecu povinně zaveden Program etické a náboženské kultury, přičemž na základě žádosti mohl ministr udělit výjimku z povinnosti uvedeného programu, pokud škola navrhla jiný, ale rovnocenný program.

Loyola High School o tuto výjimku požádala a navrhla alternativní kurz, který by byl vyučován z pohledu katolické víry a etiky. Žádost byla zamítnuta a následně přezkoumána Nejvyšším soudem. V kontextu uvedeného př́padu byl řešen problém státní regulace náboženských škol. Dle názoru generálního advokáta je legitimním zájmem státu zajistit, aby se studenti ve všech školách naučili chovat se s otevřeností a respektem ke kulturním a náboženským odlišnostem. Ovšem v daném př́padě soud dovodil, že zamítnutí žádosti o výjimku je porušením náboženské svobody a uvedl, že náboženská svoboda musí být chápána v kontextu sekulární, multikulturní a demokratické společnosti se silným zájmem na ochraně důstojnosti a různorodosti, s podporou rovnosti a se zajištěním silné společné víry v lidská práva.

\subsection{PRINCIP MULTIKULTURALISMU A ROVNÉ ZACHÁZENÍ}

V rozsudku Federálního odvolacího soudu Kanady z roku $1994^{31}$ se projednával př́pad právníka Charlese Roache, který se narodil ve státu Trinidad a Tobago, a žádal o kanadské občanství. $Z$ důvodu svých republikánských názorů ale odmítl přísahat věrnost královně a tvrdil, že požadavek takové př́sahy je porušením jeho práv podle Listiny, a to konkrétně svobody přesvědčení, názoru a projevu, svobodného sdružování a rovného zacházení. Soud ve svém rozsudku ovšem uvedl, že přísaha věrnosti žádným způsobem neomezuje žalobcova práva a svobody, nebot’ se jedná o slavnostní přistou-

30 Loyola High School v. Quebec (Attorney General), 2015 SCC 12, [2015] 1 S.C.R. 613.

31 Roach v. Can. (1994), 164 N.R. 370 (FCA). 
pení ke kanadské ústavě a národnímu životu. V disentujícím stanovisku navíc byla zdůrazněna př́lišná vzdálenost mezi přísahou věrnosti a svobodou myšlení, víry a názorů.

V roce 2007 podal pan Roach opětovně žalobu k soudu v provincii Ontario, společně se státními př́slušníky Irska, Izraele a Jamajky s žalobním důvodem, že př́saha narušuje kromě dříve uvedených svobod chráněných Listinou také svobodu myšlení. Soud prvního stupně a následně i odvolací soud potvrdily, že se nejedná o žádné pochybení ze strany státních orgánů při řizení o udělování státního občanství a následně Nejvyšší soud, který o př́padu opětovně rozhodoval v roce 2013, po smrti Charlese Roache, konstatoval, že př́saha je forma povinného projevu, a takové omezení svobody projevu je ve svobodné a demokratické společnosti ospravedlnitelné. Žalobce dle názoru Soudu nepochopil účel př́sahy, nebot' i po jejím složení mohl zůstat odpůrcem monarchie a snažit se o její zrušení. Soud odmítl posuzovat žalobcem tvrzené porušení práva na ochranu a šíření multikulturního dědictví, nebot' konstatoval, že se nejedná o ustanovení hmotného práva, které může být porušeno, protože toto ustanovení slouží pouze k účelům výkladu, nikoli k ochraně konkrétního práva či svobody.

Další př́ípad se týkal veřejných zasedání městské rady města Saguenay, ${ }^{32}$ kdy na začátku každého zasedání starosta přednesl modlitbu, kterou uvedl a zakončil naznačením symbolu kříže společně se slovy „ve jménu Otce, Syna a Ducha svatého“ a rovněž členové městské rady se pokřižovali. $V$ jedné z místností byla umístěna socha Svatého srdce s elektrickým červeným votivním světlem. $V$ další místnosti byl na zdi pověšen krucifix. Jeden z pravidelných účastníků zasedání, který sám sebe označil za ateistu, se necítil s takovými náboženskými projevy př́jemně, a obrátil se na starostu, aby této praxe zanechal. Starosta to ovšem odmítl, načež se tento účastník obrátil na př́slušnou veřejnou instituci s tím, že byla porušena jeho svoboda myšlení a náboženství. Komise své vyšetřování omezila na otázku, zda modlitba byla diskriminační a společně s účastníkem se obrátila na Tribunál pro lidská práva. Ten ve svém rozhodnutí uvedl, že přednesem modlitby byla projevena preference jednoho náboženství na úkor ostatních, což představuje porušení státní povinnosti náboženské neutrality. Modlitbou a vystavením náboženských symbolů tak došlo k porušení svobody myšlení a náboženství účastníka, které bylo nikoli nepodstatné, a takový zásah byl diskriminační. Nejvyšší soud následně uvedl, že neutralita veřejného prostoru pomáhá chránit a podporovat multikulturní povahu kanadské společnosti. Zahajování veřejných zasedání městské rady modlitbou, kterou pronášel starosta, proto bylo hodnoceno jako neslučitelné s povinností státu zachovat náboženskou neutralitu.

\section{HODNOCENÍ A ZÁVĚR}

Multikulturalismus je v Kanadě významným a užívaným konceptem, který reflektuje hodnoty etnické a kulturní rozmanitosti. Cílem kanadského multikulturalismu je ochrana všech menšin včetně těch nejzranitelnějších a jejich účinné začlenění do společnosti. Zde analyzované př́pady dokumentují vazbu mezi principem multikul-

32 Mouvement laïque québécois $v$. Saguenay (City), 2015 SCC 16, [2015] 2 S.C.R. 3. 
turalismu a ochranou lidských práv zakotvenou v Listině. Zřetelné je zejména spojení mezi principem multikulturalismu a zákazem diskriminace. Kanadské soudy k principu multikulturalismu přihližžjí také při vymezování limitu náboženské svobody a svobody projevu. Politická strategie multikulturalismu se může tedy promítat i do řešení právních sporů týkajících se kulturní odlišnosti a statusu menšin.

Z právního hlediska se může pojem multikulturalismu jevit jako těžko uchopitelný. Po úvodu do vývoje politické koncepce multikulturalismu v podmínkách postupné transformace kanadské imigrační společnosti jsme se zaměřili na relevantní právní normy a jejich výklad v judikatuře kanadských soudů. $V$ centru našeho zájmu přitom stálo ustanovení čl. 27 Listiny práv a svobod, podle něhož multikulturní dědictví Kanady má být relevantním referenčním bodem při výkladu základních lidských práv.

I v tolerantní a liberální Kanadě se kulturní, jazykové a etnické odlišnosti promítají do právních sporů, jejichž řešení záleží na výkladu lidských práv. Při zkoumání př́ípadů týkajících se svobody projevu, náboženské svobody a práva na rovné zacházení bylo zjištěno, že prríslušné soudy hodnotily celou řadu relevantních faktorů a ve svých rozhodnutích se odvolaly např. na historický koncept ústavy, veřejný pořádek či pojem sociálního míru a spravedlnosti. Už z tohoto důvodu není překvapivé, že v řadě podobných př́padů dospěly kanadské soudy k odlišným stanoviskům.

Argumentace založená na principu multikulturalismu se $\mathrm{v}$ judikatuře kanadských soudů objevuje spíše sporadicky. Z př́padů, které byly načrtnuty v tomto článku a které se týkají šíření nenávisti, vyplývá, že omezení svobody projevu může v prŕípadech veřejného podněcování $\mathrm{k}$ nenávisti být důvodné, přičemž princip multikulturalismu pomáhá stanovit limity základní svobody. Šíření nenávisti proti etnické či náboženské menšině a jejím členům je v rozporu s hodnotami multikulturní společnosti. Zdá se ovšem, že ke stejnému závěru by mohl soud dospět i v př́ípadě absence čl. 27 Listiny. Důsledná aplikace práva rovného zacházení, zákazu diskriminace a ohrožení veřejného pořádku by zřejmě dovedla soud ke stejnému výsledku.

I v př́padech souvisejících s problematikou náboženské svobody soudy odkazovaly na princip multikulturalismu spíše podpůrně. Nejvyšší soud v jednom z rozsudků uvedl, že stanovení dne odpočinku preferovaného jedním náboženstvím není souladné s ochranou a šířením multikulturního dědictví. Bylo tedy v rozporu s článkem 27 Listiny právně zavázat veřící i nevěrící pravidlem, které je zakořeněno pouze $\mathrm{v}$ křest'anských náboženských normách. Soud hodnotil princip multikulturalismu jako výzvu k přijetí sekulárního př́stupu, ovšem i zde lze konstatovat, že by dospěl ke stejnému výsledku i v př́ípadě aplikace principu rovného zacházení a zákazu diskriminace. Koncepci náboženské neutrality státu lze jistě dovodit i ze samotné podstaty náboženské svobody, která zahrnuje nejen pozitivní, ale i negativní svobodu.

Když kanadské soudy posuzovaly závaznosti dohody manželů o rozvod, která vznikla v náboženském kontextu, hrál princip multikulturalismu jen okrajovou roli, nebot' podle př́slušných soudů náboženský obsah dohody neovlivňuje její závaznost a vymahatelnost. Při srovnávání náboženské svobody a bezpečnosti silničního provozu převážil zájem na druhém z uvedených. Nejvyšší soud zdůraznil, že v multikulturní společnosti jsou nevyhnutelné konflikty mezi povinnostmi státních autorit a individuální víry. Oproti tomu výrazněji se princip multikulturalismu projevil v př́padě Loyola 
High School, protože v odůvodnění zaznělo, že náboženská svoboda musí být chápána v kontextu sekulární, multikulturní a demokratické společnosti se silným zájmem na ochraně důstojnosti a různorodosti, s podporou rovnosti a se zajištěním silné společné víry v lidská práva. Ačkoli je zřejmé, že se jednotlivé hodnoty prolínají, vzhledem k obsahu uvedeného př́padu se jeví požadavek na ochranu multikulturního dědictví jako patrnější. Tolerance odlišnosti je zcela jistě klíčovým znakem multikulturní společnosti, ale je imanentní výkladu lidských práv i v těch společnostech, které se za multikulturní neoznačují.

Ani v třetí kategorii případů uvedených $v$ tomto článků neovlivnil princip multikulturalismu právní argumentaci zásadním způsobem. Ve věci nesouhlasu s př́isahou potřebnou k získání státního občanství byla sice zohledněna ochrana svobody projevu a myšlení, ovšem hodnocené omezení se ukázalo jako ospravedlnitelné ve svobodné a demokratické společnosti. Navíc soud zdůraznil okrajovou a pouze výkladovou roli ustanovení čl. 27 Listiny, když odmítl možnost dovolávat se porušení tohoto článku samostatně. V př́ípadu Saguenay sloužil princip multikulturalismu jako určité vodítko při určování limitů používání náboženských projevů a symbolů ve veřejném prostoru, a to konkrétně na zasedání veřejného orgánu. Podle Nejvyššího soudu neutralita veřejného prostoru pomáhá chránit a podporovat multikulturní povahu kanadské společnosti.

Z praxe kanadských soudů tedy vyplývá, že koncepce multikulturalismu jako právní princip není klíčová pro řešení lidskoprávních sporů, a to přesto, že její politická a sociologická hodnota je nesporná. Odkaz a princip multikulturalismu v čl. 27 Listiny může sloužit jako podpůrný argument při stanovení limitů jednotlivých práv a svobod. Vcelku mají tyto odkazy ale spíše symbolickou hodnotu. Etnická a kulturní rozmanitost zřejmě bude i nadále častým zdrojem soudních sporů jak v Kanadě, tak i v Evropě. Ve světle kanadské praxe je pochybné, zda by přihlédnutí k principu multikulturalismu bylo pro evropské právní prostředí př́nosné. Domníváme se, že evropská doktrína lidských práv disponuje dostatečně kvalitními a osvědčenými nástroji na řešení etnické, kulturní a náboženské odlišnosti. Důsledné zkoumání legality, legitimity a proporcionality zásahů do lidských práv a práv menšin se obchází bez symboliky, která může být v politickém kontextu interpretována různě. $\mathrm{V}$ evropském kontextu by odkaz na princip multikulturalismu mohl být vnímán jako nástroj $\mathrm{k}$ ideologizaci lidských práv, která by byla z pohledu aplikace práva nejen zbytečná, ale dokonce i nebezpečná.

doc. Mag. phil. Dr. iur. Harald Christian Scheu, Ph.D., Mgr. Eliška Nováčková Právnická fakulta Univerzity Karlovy scheu@prf.cuni.cz; novackoe@prf.cuni.cz 